Article

\title{
Effect of Urine, Poultry Manure, and Dewatered Faecal Sludge on Agronomic Characteristics of Cabbage in Accra, Ghana
}

\author{
Philip Amoah ${ }^{1, *}$, Noah Adamtey ${ }^{2}$ and Olufunke Cofie ${ }^{1}$ \\ 1 International Water Management Institute (IWMI), PMB CT 112 Cantonments, Accra, Ghana; \\ o.cofie@cgiar.org \\ 2 Formerly with International Water Management Institute (IWMI), PMB CT 112 Cantonments, Accra, Ghana; \\ adamteynoah@gmail.com \\ * Correspondence: p.amoah@cgiar.org; Tel.: +233-20-815-4651 or +233-302-784-753 \\ Academic Editor: Pay Drechsel \\ Received: 31 December 2016; Accepted: 10 May 2017; Published: 19 May 2017
}

\begin{abstract}
The study was to assess the: (i) effect of human urine and other organic inputs on cabbage growth, yield, nutrient uptake, $\mathrm{N}$-use efficiency, and soil chemical characteristics; (ii) economic returns of the use of urine and/or other organic inputs as a source of fertiliser for cabbage production. To meet these objectives, participatory field trials were conducted at Dzorwulu, Accra. Four different treatments (Urine alone, Urine + dewatered faecal sludge (DFS), Urine + poultry droppings (PD), NPK (15-15-15) + PD) were applied in a Randomised Complete Block Design (RCBD) with soil alone as control. Each treatment was applied at a rate of $121 \mathrm{~kg} \cdot \mathrm{N} \cdot \mathrm{ha}{ }^{-1}$ corresponding to the Nitrogen requirement of cabbage in Ghana. Growth and yield parameters, plant nutrient uptake, and soil chemical characteristics were determined using standard protocols. There were no significant differences between treatments for cabbage head weight, or total and marketable yields. However, unmarketable yield from NPK + PD was 1 to 2 times higher $(p<0.05)$ than those from Urine + PD, Urine + DFS, and Urine alone. Seasonal effect on yields was also pronounced with higher $(p<0.001)$ cabbage head weight $(0.95 \mathrm{~kg})$ and marketable yields $\left(12.7 \mathrm{~kg} \cdot \mathrm{ha}^{-1}\right)$ in the dry season than the rainy season $\left(0.42 \mathrm{~kg}\right.$ and $\left.6.27 \mathrm{~kg} \cdot \mathrm{ha}^{-1}\right)$. There was higher $(p<0.005)$ phosphorous uptake in cabbage from Urine + PD treated soil than those from other treatments. Nitrogen $(\mathrm{N})$, phosphorous $(\mathrm{P})$, and potassium $(\mathrm{K})$ uptake in the dry season was significantly higher than the rainy season. Soils treated with Urine + DFS and Urine + PD were high in total N content. Urine + PD and Urine + DFS treated soils gave fairly high yield than PD + NPK with a net gain of US\$1452.0 and US\$1663.5, respectively. The application of urine in combination with poultry droppings has the potential to improve cabbage yields, nutrient uptake, and soil nitrogen and phosphorous content.
\end{abstract}

Keywords: cabbage yield; nutrient uptake; soil chemical characteristics; fertiliser; urban agriculture

\section{Introduction}

Globally, more people are living today in urban as opposed to rural areas. Over the span of nine decades since 1900, the global urban population increased rapidly from 2.4 million to 2.9 billion in 2000 and is expected to rise to 5 billion by 2030 [1]. The rapid population increase is expected to take place mostly in urban areas of developing countries whose population is likely to rise from about 2 billion to 4 billion in 2030, averaging 2.4 percent per year [1]. With the increasing population, absolute and relative growth in urban poverty and food insecurity are becoming a challenge for all people in urban areas.

Like most cities in developing countries, Ghana's capital city Accra is experiencing rapid population growth and urbanization. The population of Accra has increased from about 300,000 in 1960 
to about 2.3 million in 2016. This rapid urbanization has brought about urban poverty, food insecurity, and severe environmental degradation [2]. To reduce the impact of food insecurity in urban areas, several cities, including those in developed countries, have given attention to urban agriculture, which is considered as part of the urban ecological system. Earlier studies in Accra observed that up to 90 percent of the city's fresh vegetable consumption is from production within the city [3,4]. In the city, extensive urban agriculture takes place on seven main sites and there are about one thousand (1000) vegetable farmers as well as other farmers who are engaged in some seasonal crops such as maize and cassava. In addition to this, a considerable number of households are engaged in backyard gardening. As at 2004, it was estimated that about 17 hectares (ha) of land was under cultivation for maize, 20 ha under cultivation for pepper, 104 ha under cultivation for okra, and 14 ha under cultivation for tomatoes [5,6]. With the increasing use of agricultural land for residential and office buildings, the area under cultivation has reduced over the years. Farmers in some areas in Accra have lost 3 to 4 acres on average between 2009 and 2014 [7]. As a result of this phenomenon, the intensification of agriculture, which requires the use of fertilizers to maintain soil fertility, will be required.

Farmers who practice commercial vegetable production in Accra normally use poultry manure and fertilizers for their business. However, the continuous use of fertilizer and its high cost is a constraint to farmers. Hence the possibility of using alternative sources like urine and dewatered faecal sludge should be explored to enhance the productivity of urban agriculture. Human urine contains essential nutrients needed for crop production and has therefore been suggested as an alternative source of fertilizer [8-10]. It has been reported that the fertilizer value of pure urine is similar to NPK 18:2:5 [11]. The use of urine as a source of fertilizer has been tested by some researchers in Finland, South Africa, Israel, and China [12]. However, urine is not recycled yet in Ghana but released into the environment, which could lead to adverse environmental and health risks. For example, urine contains high concentrations of $\mathrm{N}$ and $\mathrm{P}$ which can cause eutrophication of receiving water bodies [13]. Can urine and dewatered faecal sludge be used as an alternative source of fertilizer in Accra and other countries in the developing world? Maybe yes; however, studies on the feasibility of urine based farming systems are limited.

This study was therefore carried out to assess (a) the effect of urine and other organic inputs and fertilizers on cabbage growth, yield, nutrient uptake, N-use efficiency, and soil chemical characteristics; (b) the economic viability of the use of urine as a source of fertilizer for cabbage production.

\section{Materials and Methods}

\subsection{The Study Area}

The study was carried out at the Dzorwulu vegetable production site in Accra, Ghana (Figure 1) during the early parts of the dry season (October to December) for the first trial and rainy seasons (April to June) for the second trial. Total rainfall during these two periods was about $130 \mathrm{~mm}$ for the dry season and $465 \mathrm{~mm}$ for the rainy seasons. Accra, the capital city of Ghana, has an estimated population of 2.3 million people [14], and between 47 ha (wet season) and 162 ha (dry season) of inner-city vegetable cultivation, engaging about 1000 farmers. Dzorwulu is one of Accra's suburbs, with a total farm area of about 12 ha under vegetable production by over 200 farmers. At this site, vegetables like lettuce, cabbage, spring onions, and green pepper are grown year-round. Most of the farmers use water from the Onyansa stream, which receives wastewater from the surrounding communities. Other farmers obtain water from household greywater drains. Most of this greywater is actually from kitchens and bathrooms. Very few farmers in Accra use piped water which is, however, not a reliable source. 

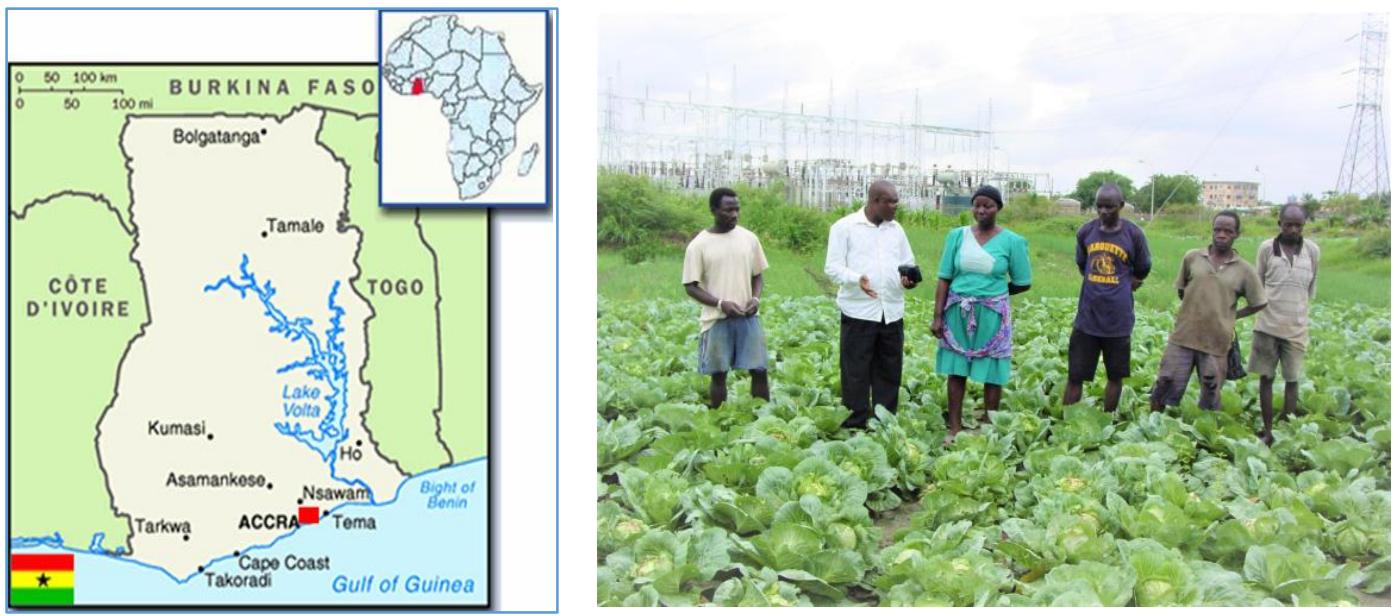

Figure 1. A map of Ghana showing Accra and a photo showing the Dzorwulu production site (photo by Philip Amoah).

\subsection{Collection of Urine, Poultry Droppings, and Faecal Sludge Used for the Trials}

Human urine used for this study was collected from a private waste company in the Central Business District (CBD) of Accra. This company was set up to provide urinals for the teeming masses of people who come to the city daily for business and other related activities. The urinals have been constructed in such a way that there was a receptacle underneath to store urine for later collection (see Appendix A). On average, about $75 \mathrm{~L}$ of urine was collected per day and stored in a $450 \mathrm{~L}$ poly tank container for one month (in the dry season) and six months (in the rainy season) to sanitize it before use. Poultry droppings (PD) were sourced from nearby poultry farms, dewatered faecal sludge (DFS) from IWMI faecal sludge drying bed at Accra, and fertilizer from retail shops.

\subsection{Physico-Chemical Analysis of Soil and the Different Fertilizer Sources}

Prior to the setting up of the field trial, the chemical characteristics of the urine and the other inputs were determined. The $\mathrm{pH}$ and electrical conductivity (EC) of PD and DFS were determined in their water slurry at a ratio of 1:5, $v / v$ using a $\mathrm{pH}$ and electrical conductivity meter [15]. The $\mathrm{PH}$ and EC of soil was determined in a soil-water slurry at a ratio of 1:1 $v / v$ [16]. Total nitrogen in the urine was determined according to the calorimetric method described by Folin and Farmer [17]. The resultant digest was used to determine phosphorus (P) and potassium (K). Phosphorus was determined calorimetrically using a spectrophotometer (model Perkin Elmer Lambda 45, Pelkin-Elma, Inc., Waltham, MA, USA). Total K was determined using a flame photometer (model Jenway PFP7, Jenway, Markham, ON, Canada). The nitrogen content of DFS, PD, and soil were determined according to the Kjeldahl method described by Okalebo et al. [17]. Inorganic nitrogen $\left(\mathrm{NH}_{4}{ }^{+}-\mathrm{N}, \mathrm{NO}_{3}{ }^{-}-\mathrm{N}\right)$ was determined from 40-mL aliquots of $2 \mathrm{M} \mathrm{KCl}$ extracts by steam distillation [18]. Total carbon content of DFS, PD, and soil was determined by dry combustion using Carbon and Sulphur Analyser Eltra CS 500 (Eltra GmBH, Haan, Germany). Total P and K of DFS, PD, and soil were determined as described above after digestion with ternary mixture $\left(20 \mathrm{~mL} \mathrm{HClO}_{4}: 500 \mathrm{~mL} \mathrm{HNO}_{3}: 50 \mathrm{~mL} \mathrm{H}_{2} \mathrm{SO}_{4}\right)$.

\subsection{Experimental Design and Treatments}

The total plot size was $11.4 \mathrm{~m} \times 20.4 \mathrm{~m}$ (Figure 2a) and each experimental unit was $3.8 \mathrm{~m} \times 3.4 \mathrm{~m}$ consisting of four rows of 28 plants, and the planting distance was $60 \mathrm{~cm} \times 45 \mathrm{~cm}$ (Figure 2b). Each experimental plot was replicated three times. The following treatments: urine alone, urine + dewatered faecal sludge (Urine + DFS), urine + poultry droppings (Urine + PD), and NPK 15-15-15 + poultry droppings (NPK + PD) were applied in a Randomised Complete Block Design (RCBD). Soil alone served as a control. 


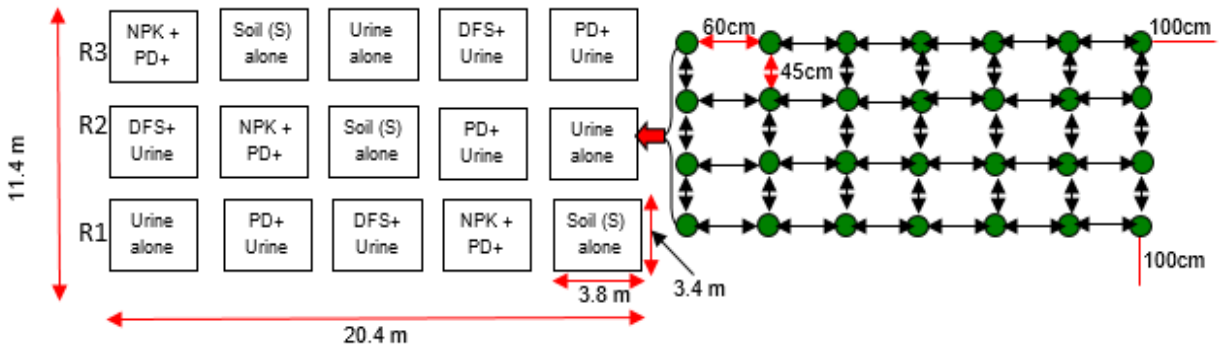

(a)

(b)

Figure 2. (a) Experimental design (RCBD) of the trial. The "first, second and third rows" and "R1, R2 and R3" show the replicates of each treatment; (b) Experimental unit showing plant spacing (Within row spacing is $60 \mathrm{~cm}$ and between row spacing is $45 \mathrm{~cm}$. Spacing between two experimental units is $100 \mathrm{~cm}$ ).

\subsection{Field Management Activities}

Cabbage (Brassica oleraria var. capitata) seeds were nursed for about two weeks and seedlings of similar height and girth were transplanted onto the permanent plots. Treatments were applied twice: three days after transplanting and a month after emergence at a rate of $121 \mathrm{~kg} \cdot \mathrm{N} \cdot \mathrm{ha}{ }^{-1}$ [18]. In the case of urine, application was done in the evening after the soil was slightly wet with water to avoid volatilization. Urine was applied in holes dug at $20 \mathrm{~cm}$ away from the plants to avoid 'crop burning' which were 1 to $4 \mathrm{~cm}$ deep. The holes were covered with soil immediately after urine application. This simple practice mimics the successful injection technique used by Richert Stintzing et al. [19] to avoid ammonia losses. Crops grown in the dry season received supplementary irrigation. Weeds, pests, and diseases were controlled as and when necessary.

\subsection{Data Collection}

Growth parameters, number of leaves, cabbage canopy, and plant height were measured forth nightly through counting, use of calipers, and the meter rule, respectively. The measurements were performed for six weeks after which there were no differences in the above growth parameters. Yield parameters (circumference of cabbage head, fresh weight of cabbage head, and dry matter yield of above ground cabbage plants) were determined at maturity using calipers and a digital weighing scale. Cabbage heads without any damage were sorted and classified as marketable yields whilst those that had rotten were classified as unmarketable yields. The total cabbage heads in each of the plots were used to express the fresh yields on a per hectare basis.

\subsection{Plant Nutrint Uptake, Nitriogen Use Efficiency, and Soil Analysis}

Five cabbage plants (above ground portion) per treatment were chopped into pieces and oven dried at $70{ }^{\circ} \mathrm{C}$ for two weeks (when no observable changes were observed in the weight). The dry weight was then taken and expressed on a per hectare basis. For plant nutrient content analyses, dried samples were randomly selected from the bulk plants and milled. After that, $0.1 \mathrm{~g}$ of the milled samples per treatment was taken and digested using ternary mixture as described above. The N, $\mathrm{P}$, and $\mathrm{K}$ content of the digest was determined according to the procedure described by Okalebo et al. [17]. Plant nutrient uptake was calculated as shown in Equation (1):

$$
\text { Nutrient uptake }\left(\frac{\mathrm{kg}}{\mathrm{ha}}\right)=\frac{\text { nutrient content } x \text { sample dry weight }\left(\begin{array}{l}
\mathrm{kg} \\
\mathrm{ha}
\end{array}\right)}{100}
$$

Apparent $\mathrm{N}$ recovery efficiency (ANR) and Agronomic N-use efficiency (AE) of cabbage were calculated according to the procedure of Adamtey [18] as shown in Equations (2) and (3): 


$$
\begin{gathered}
\mathrm{ANR}=\frac{\mathrm{Nf}-\mathrm{N} 0}{\mathrm{~N}} \times 100 \\
\mathrm{AE}=\frac{\mathrm{CabYf}-\mathrm{CabY0}}{\mathrm{N}}
\end{gathered}
$$

where $\mathrm{Nf}=$ nitrogen uptake from fertilized plots $\left(\mathrm{kg} \cdot \mathrm{N} \cdot \mathrm{ha}^{-1}\right), \mathrm{N} 0=$ nitrogen uptake from unfertilized plots $\left(\mathrm{kg} \cdot \mathrm{N} \cdot \mathrm{ha}^{-1}\right), \mathrm{CabYf}=$ cabbage yield from fertilized plots $\left(\mathrm{kg}\right.$ cabbage $\left.\cdot \mathrm{ha}^{-1}\right), \mathrm{CabY0}=$ cabbage yield from unfertilized plots $\left(\mathrm{kg}\right.$ cabbage $\left.\mathrm{ha}^{-1}\right)$, and $\mathrm{N}=$ Total nitrogen applied per hectare $\left(\mathrm{kg} \cdot \mathrm{N} \cdot \mathrm{ha}^{-1}\right)$.

After harvesting of the cabbage, five soil samples were collected per plot using the diagonal method. Thereafter, the samples were homogenously mixed together to form a composite for each treatment. The samples were air dried and sieved through a 2-mm mesh. After that, $0.3 \mathrm{~g}$ soil per treatment was taken and digested using ternary mixture as described above. The, N, P, and K content of the digest was determined according to the method described by Okalebo et al. [17]. Similarly, the soil $\mathrm{pH}, \mathrm{EC}, \mathrm{NH}_{4}{ }^{+}-\mathrm{N}$, and $\mathrm{NO}_{3}{ }^{-}-\mathrm{N}$ were also measured according to the methods already described above.

\subsection{Financial Analysis}

A partial budgeting method was used to assess the financial effect of incremental changes from shifting from NPK + PD to Urine + PD or Urine + DFS. Partial Budgeting Analysis compares the profitability of one alternative, typically current farmer practice, with a proposed change or new alternative [20]. Offei et al. [21] provides useful data (Table 1) for the economic analysis at the time of the experiment. There is no market price for the sale of urine in Ghana and therefore a price of $\mathrm{GH} \not 0.30$ per $20 \mathrm{~L}$ of urine was assumed on the basis that $20 \mathrm{~L}$ of urine costs $\mathrm{GH} \not 0.29$ (\$0.20) [22] in neighbouring Burkina Faso. The cost of dried faecal sludge was also assumed to be the same as poultry droppings. Again, the cost of all other agronomic practices (apart from the different fertilizer sources) were assumed to be the same.

Table 1. Estimated costs of inputs used to estimate the savings made when organic fertilizer is used

\begin{tabular}{|c|c|}
\hline Input & Cost \\
\hline 50 kg NPK (15-15-15) fertilizer & GHф55.1 (\$38.0) \\
\hline $50 \mathrm{~kg}$ of PD & $\mathrm{GH} \not 0.6(\$ 0.4)$ \\
\hline $20 \mathrm{~L}$ of urine & $\mathrm{GH} \not 0.30(\$ 0.2)$ \\
\hline $\mathrm{U}+\mathrm{PD}(61.4 \mathrm{~kg} \mathrm{PD}+117.4 \mathrm{~L} \mathrm{U}) / 200 \mathrm{~m}^{2}$ plot & GHœ3.7 \\
\hline PD + NPK (61.4 kg PD + $8.1 \mathrm{~kg}$ NPK) $/ 200 \mathrm{~m}^{2}$ plot & $\mathrm{GH} \not 10.9$ \\
\hline
\end{tabular}
instead of inorganic fertilizer.

NPK = Nitrogen, Phosphorus and Potassium. Source: [21].

\subsection{Statistical Analysis}

Data collected were subjected to statistical analysis with a linear mixed model using the function 'Imer' from the 'Ime4' package [23] in the statistical software R (version 3.2.5, [24]). The linear model included treatment, seasons, and their interaction as fixed factors, whilst replicates was used as random factor. Means separation was done using the Tukey method (i.e., 'lsmeans' and 'cld' functions from the 'Ismeans' package) [25]. We tested slope difference between damaged cabbage head (rotten cabbage) and nitrogen uptake with 'lmertest' [26].

\section{Results}

\subsection{Physico-Chemical Characteristics of the Different Nutrient Sources Used in the Treatments}

The physico-chemical characteristics of the different inputs used for the rainy and dry season trials are as shown in Table 2. The pH of DFS (5.4) and PD (6.8) were low compared to Urine (7.9 and 8.5). The electrical conductivity of urine and DFS was also very high. The nitrogen and phosphorus contents of DFS was higher than that of urine and PD. The potassium content of PD was about twice that of the DFS and urine. 
Table 2. Characteristics of soil and inputs used for dry and rainy season cabbage cultivation in Dzorwulu, Accra.

\begin{tabular}{|c|c|c|c|c|c|c|c|c|}
\hline \multirow{2}{*}{ Soil/Treatment } & \multirow{2}{*}{$\mathrm{pH}$} & EC & $\mathrm{C}$ & $\mathrm{N}_{\text {tot }}$ & $\mathrm{NH}_{4}-\mathrm{N}$ & $\mathrm{NO}_{3}-\mathrm{N}$ & $P_{\text {tot }}$ & $K_{\text {tot }}$ \\
\hline & & $\mathrm{dSm}^{-1}$ & $\mathrm{~g} \cdot \mathrm{kg}^{-1}$ & $\mathrm{~g} \cdot \mathrm{kg}^{-1}$ & $\mathrm{mg} \cdot \mathrm{kg}^{-1}$ & $\mathrm{mg} \cdot \mathrm{kg}^{-1}$ & $\mathrm{~g} \cdot \mathrm{kg}^{-1}$ & $\mathrm{~g} \cdot \mathrm{kg}^{-1}$ \\
\hline Soil $^{1}$ & $7.05 \pm 0.02$ & $0.28 \pm 0.00$ & $136.37 \pm 0.17$ & $0.49 \pm 0.01$ & $38.00 \pm 1.03$ & $9.14 \pm 0.18$ & $0.50 \pm 0.00$ & $0.23 \pm 0.00$ \\
\hline Soil $^{2}$ & $7.40 \pm 0.16$ & $0.42 \pm 0.13$ & na & $0.27 \pm 0.03$ & $25.12 \pm 4.02$ & $6.65 \pm 0.70$ & $0.59 \pm 0.03$ & $0.54 \pm 0.12$ \\
\hline Urine $^{3}$ & $8.45 \pm 0.02$ & $>3.00$ & na & $10.30 \pm 0.00$ & na & na & $1.07 \pm 0.11$ & $7.50 \pm 0.00$ \\
\hline Urine $^{4}$ & $7.91 \pm 0.01$ & na & na & $9.07 \pm 0.22$ & $343.98 \pm 0.10$ & $354.51 \pm 7.20$ & $0.30 \pm 0.00$ & $8.10 \pm 0.00$ \\
\hline PD & $6.80 \pm 0.00$ & $1.65 \pm 0.00$ & $154.10 \pm 0.05$ & $19.63 \pm 0.32$ & $740.38 \pm 17.50$ & $26.40 \pm 0.30$ & $19.40 \pm 3.48$ & $12.18 \pm 0.24$ \\
\hline DFS & $5.40 \pm 0.00$ & $>3.00$ & $10.58 \pm 0.00$ & $22.64 \pm 0.40$ & $489.22 \pm 0.00$ & $83.72 \pm 0.00$ & $28.17 \pm 0.49$ & $5.01 \pm 0.80$ \\
\hline
\end{tabular}

C, total carbon; $\mathrm{N}_{\text {tot }}$, total nitrogen; $\mathrm{P}_{\text {tot }}$, total phosphorous; $\mathrm{K}_{\mathrm{tot}}$, total potassium; PD, poultry droppings; DFS, dewatered faecal sludge; na, non-applicable; ${ }^{1}$ Soil characteristics at the beginning of the dry season trial;

${ }^{3}$ Soil and urine characteristics at the beginning of the dry season trial; ${ }^{2}$ Soil characteristics at the beginning of the rainy season trial; ${ }^{4}$ Soil and urine characteristics at the beginning of the rainy season trial.

\subsection{Effect of Different Nutrient Sources on Cabbage Growth and Yield}

The treatments had similar effects on cabbage growth (e.g., plant height, number of leaves, and plant canopy) (Table 3). However, there was seasonal effect on cabbage growth, with higher $(p<0.01)$ plant height and canopy formation in the dry season compared to those grown in the rainy season. The average cabbage head weight, circumference, and total and marketable fresh yields were similar for all the treatments. The unmarketable yields decreased in the order of NPK + PD $>$ Urine + PD $>$ Urine + DFS $>$ Urine alone $>$ soil. The treatment also showed similar effect on dry matter yields, except in soil alone which was significantly lower. Cabbage yields was affected by the season with higher $(p<0.001)$ head weight, total and marketable fresh yields in the dry season compared to those from the rainy season. The unmarketable yields were also three times higher $(p>0.001)$ in the dry season compared to those from the rainy season. In contrast, the circumference of cabbage head was higher $(p<0.001)$ in the rainy season than the dry season.

\subsection{Effect of Urine and Other Sources of Organic Inputs and Fertilizer on Nutrient Uptake and N Use Efficiency}

The N, P, and K uptake from soil treated with Urine + PD was higher $(p<0.01,0.001)$ than the uptakes from soil alone (Table 4). Although not statistically significant, it is worth mentioning that the N uptake in Urine + PD treated soil was between $23 \%$ and $35 \%$ higher than the uptake in NPK + PD, Urine alone, and Urine + DFS treated soils. The P uptake in Urine + PD treated soil was $28 \%$ and $30 \%$ higher compared to the uptake in Urine + DFS, Urine alone, and NPK + PD treated soils. Similarly, K uptake was $23 \%, 25 \%$, and $36 \%$ high in Urine + PD treated soil compared to the uptake in NPK + PD, Urine alone, and Urine + DFS treated soils. The $\mathrm{N}$ recovery efficiency was in the order of Urine $+\mathrm{PD}$, $>$ NPK + PD and $>$ Urine alone $>$ Urine + DFS. The nutrient uptake and N-recovery efficiency in the dry season was higher $(p<0.001)$ than uptake and $\mathrm{N}$-recovery efficiency in the rainy season.

\subsection{Effect of Urine and Other Sources of Organic Inputs and Fertilizer on Soil Characteristics}

The treatments had similar effect on the change in soil chemical characteristics (Table 5). There was, however, an interactive effect of the treatment and season on soil $\mathrm{NO}_{3}{ }^{-}-\mathrm{N}$ content. At the end of the dry season, the soil treated NPK + PD was $25 \%$ to $40 \%$ higher in $\mathrm{NO}_{3}-\mathrm{N}$ compared to the soil treated with Urine alone, Urine + PD, and Urine + DFS. On the other hand, at the end of the rainy season, the soil treated with Urine $+\mathrm{PD}$ was higher $(p<0.05)$ in $\mathrm{NO}_{3}-\mathrm{N}$ content compared to those treated with Urine + DFS, NPK + PD, Urine alone, or soils without any amendment. The soils treated with Urine + DFS and Urine + PD were fairly high in total N content. Whilst those treated with NPK + PD and Urine + PD were also fairly high in total P content. As per soil electrical conductivity (EC), although it was not significantly different among the treatments, it is important to mention that the soil EC almost doubled for all the treatments including soil alone. The soils at the end of rainy season showed higher $(p<0.05,0.001)$ soil $\mathrm{pH}, \mathrm{N}, \mathrm{P}$, and $\mathrm{K}$. content compared to those at the end of dry season cropping. 
Table 3. Effect of urine, organic inputs, and fertilizer on growth and yield of cabbage in Dzorwulu, Accra.

\begin{tabular}{|c|c|c|c|c|c|c|c|c|c|c|}
\hline \multirow{3}{*}{ Season } & \multirow{3}{*}{ Treatment } & \multicolumn{3}{|c|}{ Growth Parameter } & \multicolumn{2}{|c|}{ Yield Parameter } & \multicolumn{4}{|c|}{ Yield } \\
\hline & & $\begin{array}{c}\text { Plant } \\
\text { Height }\end{array}$ & $\begin{array}{c}\text { Number } \\
\text { of Leaves }\end{array}$ & $\begin{array}{c}\text { Plant } \\
\text { Canopy }\end{array}$ & $\begin{array}{c}\text { Head } \\
\text { Weight }\end{array}$ & $\begin{array}{c}\text { Head } \\
\text { Circumference }\end{array}$ & $\begin{array}{c}\text { Total } \\
\text { (Fresh) }\end{array}$ & $\begin{array}{c}\text { Marketable } \\
\text { (Fresh) }\end{array}$ & $\begin{array}{l}\text { Unmarketable } \\
\text { (Fresh) }\end{array}$ & Total (Dry) \\
\hline & & $\mathrm{cm}$ & & $\mathrm{cm}$ & kg & $\mathrm{cm}$ & t.ha $a^{-1}$ & $t \cdot h a^{-1}$ & $t \cdot h a^{-1}$ & $t \cdot h a^{-1}$ \\
\hline \multicolumn{11}{|c|}{ Treatments } \\
\hline & Soil & 20.4 & 16.9 & 55.0 & 0.6 & 48.4 & 10.4 & 7.6 & $2.8 \mathrm{~b}$ & $0.9 \mathrm{~b}$ \\
\hline & Urine & 20.9 & 17.3 & 57.2 & 0.6 & 50.8 & 13.9 & 10.3 & $3.7 \mathrm{ab}$ & $1.2 \mathrm{ab}$ \\
\hline & Urine + DFS & 20.3 & 18.2 & 53.5 & 0.7 & 50.3 & 15.0 & 10.9 & $4.1 \mathrm{ab}$ & $1.2 \mathrm{ab}$ \\
\hline & Urine + PD & 21.9 & 18.1 & 56.2 & 0.8 & 50.9 & 16.2 & 10.1 & $6.1 \mathrm{ab}$ & $1.4 \mathrm{a}$ \\
\hline & NPK + PD & 21.7 & 16.5 & 53.1 & 0.8 & 49.4 & 15.0 & 7.2 & $7.7 \mathrm{a}$ & $1.2 \mathrm{ab}$ \\
\hline \multicolumn{11}{|c|}{ Seasons } \\
\hline & Dry $^{a}$ & $22.1 \mathrm{a}$ & 17.6 & $57.0 \mathrm{a}$ & $1.0 \mathrm{a}$ & $46.8 \mathrm{~b}$ & $19.7 \mathrm{a}$ & $12.2 \mathrm{a}$ & $7.5 \mathrm{a}$ & $1.9 \mathrm{a}$ \\
\hline & Rainy $^{b}$ & $20.0 \mathrm{~b}$ & 17.2 & $52.9 \mathrm{~b}$ & $0.4 \mathrm{~b}$ & $53.1 \mathrm{a}$ & $8.4 \mathrm{~b}$ & $6.3 \mathrm{~b}$ & $2.1 \mathrm{~b}$ & $0.4 \mathrm{~b}$ \\
\hline \multicolumn{11}{|c|}{ Seasons $\times$ Treatments } \\
\hline \multirow[t]{5}{*}{ Dry $^{a}$} & Soil & 21.7 & 17.0 & 58.6 & 0.9 & 44.5 & 15.6 & 10.9 & 4.7 & 1.5 \\
\hline & Urine & 21.0 & 17.7 & 58.9 & 0.9 & 46.1 & 19.8 & 13.6 & 6.1 & 1.9 \\
\hline & Urine + DFS & 21.5 & 18.7 & 55.0 & 1.0 & 48.7 & 20.9 & 14.8 & 6.1 & 2.0 \\
\hline & Urine + PD & 23.2 & 17.7 & 57.1 & 1.0 & 46.4 & 21.3 & 13.0 & 8.3 & 2.2 \\
\hline & NPK + PD & 23.3 & 17.0 & 55.6 & 1.0 & 48.4 & 21.1 & 8.6 & 12.5 & 2.0 \\
\hline \multirow{5}{*}{ Rainy $^{b}$} & Soil & 19.0 & 16.8 & 51.4 & 0.3 & 52.3 & 5.1 & 4.3 & 0.8 & 0.3 \\
\hline & Urine & 20.9 & 16.9 & 55.5 & 0.4 & 55.6 & 8.0 & 6.9 & 1.2 & 0.4 \\
\hline & Urine + DFS & 19.1 & 17.8 & 51.8 & 0.4 & 51.8 & 9.1 & 7.1 & 2.0 & 0.4 \\
\hline & Urine + PD & 20.6 & 18.6 & 55.4 & 0.5 & 55.4 & 11.1 & 7.3 & 3.8 & 0.5 \\
\hline & NPK + PD & 20.2 & 15.9 & 50.3 & 0.5 & 50.3 & 8.6 & 5.8 & 2.8 & 0.3 \\
\hline \multicolumn{11}{|c|}{ Source of variation } \\
\hline & Treatment & ns & ns & ns & ns & ns & ns & ns & $*$ & $*$ \\
\hline & Season & $* *$ & ns & $* *$ & $* * *$ & $* * *$ & $* * *$ & $* * *$ & $* * *$ & $* * *$ \\
\hline Treatm & $\times$ Season & ns & $\mathrm{ns}$ & $\mathrm{ns}$ & ns & ns & ns & ns & ns & ns \\
\hline
\end{tabular}

DFS, dewatered faecal sludge; PD, poultry droppings; NPK , NPK-15-15-15; ns, not significant; ${ }^{\text {a }}$ dry season cropping received supplementary irrigation; ${ }^{\mathrm{b}}$ rainy season cropping was solely under rain fed conditions; NB: Different letters (a and b) indicate that sample means are significantly different between treatment, season, or their interaction $\left({ }^{*} p<0.05 ; * *<<0.01\right.$; *** $p<0.001$ ); if a significant interaction was found, letters for significant difference between season or treatments are not shown. 
Table 4. Effect of urine, organic inputs, and fertilizer on nutrient uptake and nitrogen use efficiency in Dzorwulu, Accra.

\begin{tabular}{|c|c|c|c|c|c|c|}
\hline \multirow{3}{*}{ Season } & \multirow{3}{*}{ Treatment } & \multicolumn{3}{|c|}{ Uptake } & \multirow{2}{*}{ N Recovery Efficiency } & \multirow{2}{*}{ Agronomic N Use Efficiency } \\
\hline & & $\mathbf{N}$ & $\mathbf{P}$ & $\mathbf{K}$ & & \\
\hline & & $\mathrm{kg} \cdot \mathrm{ha}^{-1}$ & $\mathrm{~kg} \cdot \mathrm{ha}^{-1}$ & $\mathrm{~kg} \cdot \mathrm{ha}^{-1}$ & $\%$ & $\mathrm{~kg} \cdot \mathrm{kg}^{-1} \mathrm{~N}$ \\
\hline \multicolumn{7}{|c|}{ Treatments } \\
\hline & Soil & $20.7 \mathrm{~b}$ & $5.2 \mathrm{~b}$ & $26.0 \mathrm{~b}$ & na & na \\
\hline & Urine & $28.3 \mathrm{ab}$ & $6.7 \mathrm{~b}$ & $34.6 \mathrm{ab}$ & $<0.0$ & $<0.0$ \\
\hline & Urine + DFS & $27.4 \mathrm{ab}$ & $6.8 \mathrm{ab}$ & $31.9 \mathrm{~b}$ & $<0.0$ & 3.3 \\
\hline & Urine + PD & $37.0 \mathrm{a}$ & $8.7 \mathrm{a}$ & $43.4 \mathrm{a}$ & $<0.0$ & 27.3 \\
\hline & NPK + PD & $30.0 \mathrm{ab}$ & $6.7 \mathrm{~b}$ & $35.3 \mathrm{ab}$ & 9.5 & $<0.0$ \\
\hline \multicolumn{7}{|c|}{ Seasons } \\
\hline & Dry $^{a}$ & $48.6 \mathrm{a}$ & $10.5 \mathrm{a}$ & $52.7 \mathrm{a}$ & 17.2 & 13.0 \\
\hline & Rainy ${ }^{b}$ & $8.8 \mathrm{~b}$ & $3.2 \mathrm{~b}$ & $16.8 \mathrm{~b}$ & $<0.0$ & $<0.0$ \\
\hline \multicolumn{7}{|c|}{ Seasons $\times$ Treatments } \\
\hline \multirow[t]{5}{*}{ Dry $^{a}$} & Soil & 35.5 & 8.2 & 40.8 & $\mathrm{Na}$ & na \\
\hline & Urine & 48.0 & 10.2 & 52.4 & $17.0 \mathrm{a}$ & 22.5 \\
\hline & Urine + DFS & 46.1 & 10.4 & 49.8 & $13.1 \mathrm{ab}$ & 32.0 \\
\hline & Urine + PD & 60.0 & 13.2 & 63.9 & $20.3 \mathrm{a}$ & 17.0 \\
\hline & NPK + PD & 53.3 & 10.6 & 56.6 & $18.5 \mathrm{a}$ & $<0.0$ \\
\hline \multirow[t]{5}{*}{ Rainy b } & Soil & 6.0 & 2.1 & 11.1 & $<.0 .0$ & $<0.0$ \\
\hline & Urine & 8.7 & 3.3 & 16.8 & $<0.0$ & $<0.0$ \\
\hline & Urine + DFS & 8.7 & 3.3 & 14.1 & $<0.0$ & 22.7 \\
\hline & Urine + PD & 14.1 & 4.3 & 22.9 & $<0.0$ & $<0.0$ \\
\hline & NPK + PD & 6.6 & 2.8 & 14.1 & $0.5 \mathrm{~b}$ & $<0.0$ \\
\hline \multicolumn{7}{|c|}{ Source of variation } \\
\hline & Treatment & $* *$ & $* * *$ & $* *$ & $* * *$ & ns \\
\hline & Season & $* * *$ & $* * *$ & $* * *$ & $* * *$ & ns \\
\hline Treatn & t $\times$ Season & ns & ns & ns & $* * *$ & ns \\
\hline
\end{tabular}

N, nitrogen; P, Phosphorous; K, Potassium; DFS, dewatered faecal sludge; PD, poultry droppings; NPK, NPK-15-15-15; ns, not significant; a dry season cropping received supplementary irrigation; ${ }^{b}$ rainy season cropping was solely under rain fed conditions; NB: Different letters ( $a$ and $b$ ) indicate that sample means are significantly different between treatment, season or their interaction $\left(* p<0.05 ;{ }^{* *} p<0.01 ; * * *<0.001\right)$; if a significant interaction was found, letters for significant difference between season or treatments are not shown; $\times$ means interactions between treatment and season. 
Table 5. Effect of urine, organic inputs, and fertilizer on soil chemical characteristics in Dzorwulu, Accra.

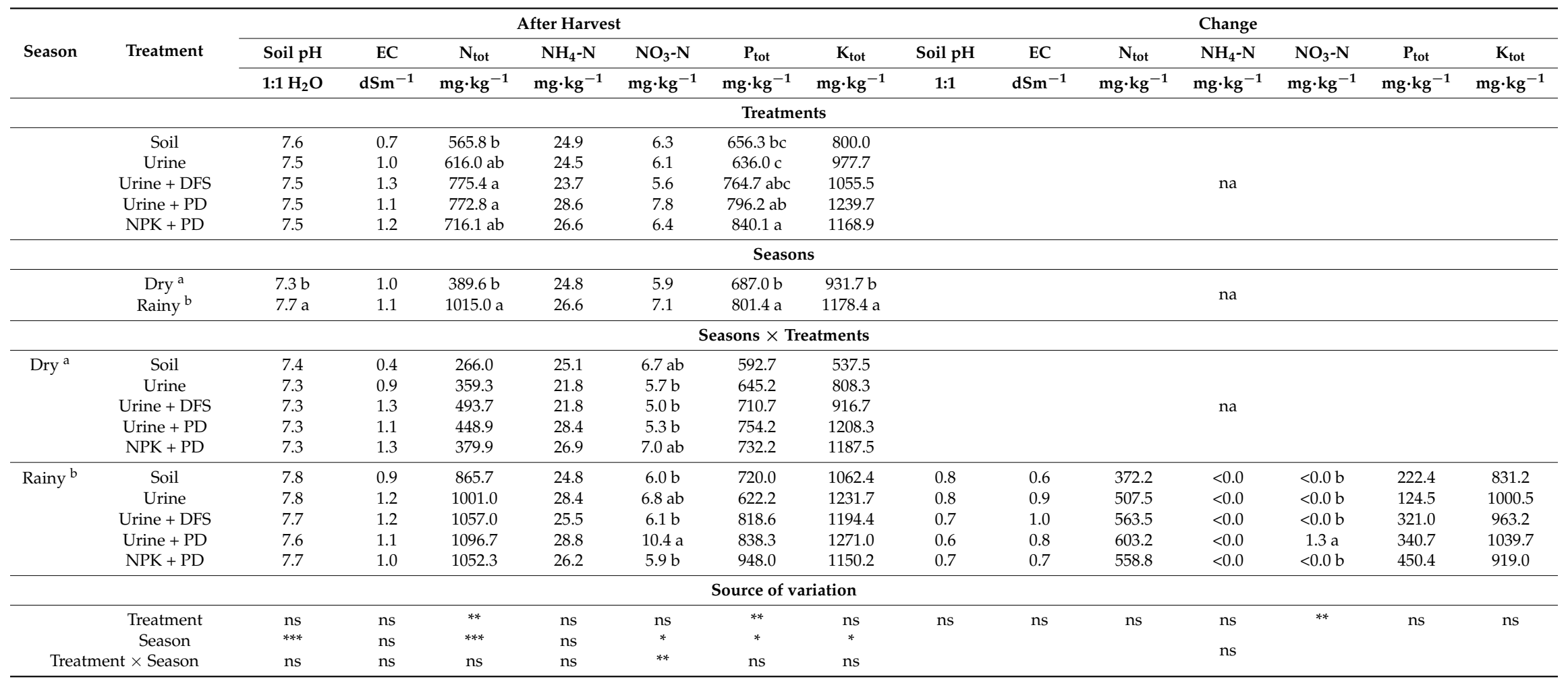

DFS, dewatered faecal sludge; PD, poultry droppings; NPK, NPK-15-15-15; C, total carbon; $\mathrm{N}_{\text {tot }}$, total nitrogen; $\mathrm{P}_{\text {tot }}$, total phosphorous; $\mathrm{K}_{\text {tot }}$, total potassium; na, non-applicable; ns, not significant; ${ }^{a}$ dry season cropping received supplementary irrigation; ${ }^{b}$ rainy season cropping was solely under rain fed conditions; NB: Different letters (a, $b$, and c) indicate that sample means are significantly different between treatment, season or their interaction $\left({ }^{*} p<0.05\right.$; ${ }^{* *} p<0.01$; $\left.{ }^{* * *} p<0.001\right)$; if a significant interaction was found, letters for significant difference between season or treatments are not shown. $\times$ means interactions between treatment and season. 


\subsection{Financial Analysis}

Table 6 details the result of the financial analysis of using different fertilizer sources for cabbage production. The results showed that, in one cropping cycle, it would cost a farmer US\$370.4 to crop a hectare of cabbage using NPK + PD to get a yield of $7.2 \mathrm{t} \cdot \mathrm{ha}^{-1}$ of fresh marketable cabbage and revenue of US\$2925.4. When the NPK + PD is replaced with $U+P D$, the result of the partial budgeting analysis showed that a farmer increases his yield by $40.3 \%\left(2.9 \mathrm{t} \cdot \mathrm{ha}^{-1}\right)$, with a savings of US\$244.4 on the cost of fertilizer (Table 7). Similarly, switching from NPK + PD to U + DFS increases a farmers' yield by $51.4 \%\left(3.7 \mathrm{t} \cdot \mathrm{ha}^{-1}\right)$, with a cost savings of US\$133.6. Thus, U + PD and U + DFS give a comparable high yield to PD + NPK and with a net gain of US\$1452.0 and US\$1663.5, respectively.

Table 6. Financial analysis of the investment into urine and dry faecal sludge use to replace the use of inorganic NPK fertilizer.

\begin{tabular}{ccccc}
\hline \multirow{2}{*}{ Treatment } & $\begin{array}{c}\text { Marketable } \\
\text { Yield }\end{array}$ & $\begin{array}{c}\text { Total Cost of } \\
\text { Treatment ha }\end{array}$ & $\begin{array}{c}\text { Total Revenue } \\
\text { ha }^{-1}\end{array}$ & $\begin{array}{c}\text { Gains } \\
\text { ha }^{\mathbf{1}}\end{array}$ \\
\cline { 2 - 5 } & ha $^{-\mathbf{1}}$ & (US\$) & (US\$) & (US\$) \\
\hline $\begin{array}{c}\text { NPK + PD } \\
(3,071.4 \mathrm{~kg} \mathrm{PD} \mathrm{+} \mathrm{403.8} \mathrm{kg} \mathrm{NPK)}\end{array}$ & 7.2 & 370.4 & 2925.4 & 2555.0 \\
\hline $\begin{array}{c}\text { U + PD } \\
(3,071.4 \mathrm{~kg} \text { PD + 5,872.0 L U) }\end{array}$ & 10.1 & 126.0 & 4133.0 & 4007.1 \\
\hline $\begin{array}{c}\text { U + DFS } \\
(5,872.0 \mathrm{~kg} \text { PD + 2950.2 kg DFS) }\end{array}$ & 10.9 & 236.8 & 4455.4 & 4218.5 \\
\hline
\end{tabular}

${ }^{1}$ This does not include the cost of all other agronomic practices apart from the different fertilizer sources used. $1 \mathrm{GH} \phi=\mathrm{US} \$ 0.68$; Source: adopted from [21].

Table 7. Result of partial budget analysis of the use of urine and fry faecal sludge to replace the use of inorganic NPK fertilizer.

\begin{tabular}{ccc}
\hline \multirow{2}{*}{ Change in Yield/cost/total Returns } & \multicolumn{2}{c}{ Recommended Treatments } \\
\cline { 2 - 3 } & U + PD & U + DFS \\
\hline Change in Yield (tons/ha) & 2.9 & 3.7 \\
Change in cost (US\$) & 244.4 & 133.6 \\
\hline Change in total returns (US\$) & 1207.6 & 1530.0 \\
\hline Net Gain (US\$) & 1452.0 & 1663.6 \\
\hline Source: adopted from [21].
\end{tabular}

\section{Discussion}

Generally, the urine, dewatered faecal sludge (DFS), and poultry droppings (PD) used in the trials contain appreciable levels of nutrients. This indicates that the organic inputs are essential sources for plant nutrients and a soil conditioner in agriculture. Human urine and or faeces as sources of plant nutrients have been studied and confirmed in countries like South Africa, Zimbabwe [27], Ethiopia, Mozambique, Benin, Burkina Faso, Senegal, Cote d'Ivoire, Togo, Mali, Mexico [28], China, Sweden [29-31], and Germany [32]. This study also confirms the high nutrient levels in human excreta.

The total nitrogen concentration $\left(1.03 \%\right.$ or $\left.10.3 \mathrm{~g} \cdot \mathrm{L}^{-1}\right)$ was within the range $(0.7-1.1 \%$ or 7-11 g. $\mathrm{L}^{-1}$ ) reported in other studies for undiluted fresh human urine [33-35]). The total nitrogen and phosphorus content of urine reduced after six months of storage, whereas the potassium content remained fairly the same. The reduction in the nitrogen content was due to volatilization exacerbated by a longer storage period (six months), whilst that of phosphorous was due to precipitation. According to Udert et al. [36], about 95 to 100 percent of $\mathrm{P}$ in fresh urine is bound as dissolved phosphate. During storage, increased in urine $\mathrm{pH}$ trigged $\mathrm{P}$ to precipitate into struvite $\left[\mathrm{MgNH}_{4} \mathrm{PO}_{4} \cdot 6 \mathrm{H}_{2} \mathrm{O}\right]$ and 
hydroxyapatite $\left[\mathrm{Ca}_{5}\left(\mathrm{PO}_{4}\right)_{3}(\mathrm{OH})\right][37,38]$ which is finally deposited in the bottom of the storage tank. This may explain the low $\mathrm{P}$ content of urine under storage. To decrease the risk of loss of nitrogen during storage, the authors recommend urine to be stored in a sealed tank or container under a shed for a shorter time period (about a month). The precipitated $\mathrm{P}$ should also be removed and applied to the crops.

There were fairly high unmarketable yields from soils treated with NPK + PD and Urine + PD. This was as a result of rottenness. Pradan et al. [33] reported that higher N uptake by cabbage might promote succulent plant parts which could make the crop susceptible to various forms of damage. In the current study, however, there was no significant correlation between plant $\mathrm{N}$ uptake and rottenness or unmarketable yields. There is therefore the need to conduct further research to ascertain the cause of the high level of rottenness.

The average cabbage weight per head $(0.6$ to $0.8 \mathrm{~kg})$ obtained for all the treatments was fairly low compared to the values reported from several farms (1.1-1.2 kg) in Ghana [39]. This was due to the poor performance of the crop in the rainy season as a result of heavy rainfall and flooding that occurred over the period of crop growth. This also explains the significantly lower head weight, and total and marketable yields in the rainy season compared to the dry season. The flood washed the soil and nutrients away and was also expected to affect the net photosynthetic rate [40], and hence might explain the poor plant growth and low yields in the rainy season. Compared to yields reported from several farms in Ghana (30 to 40 tone ha ${ }^{-1}$ ), the cabbage yields obtained from this study were very low. This may be attributed to varietal differences, poor crop performance due to the above-mentioned reason, and rottenness of cabbage head (the cost of which has not yet been ascertained). There was fairly high N, P, and K uptake from soils treated with Urine + PD; this can be attributed to the higher $\mathrm{N}$ and $\mathrm{K}$ content of urine and PD. This was expected to account for the increase in dry matter yield. Pradhan et al. [33] similarly reported fairly high dry matter yields from Urine + PD treatments compared to NPK + PD treatments. There was significantly higher P uptake from Urine + PD and $\mathrm{NPK}+\mathrm{PD}$ treated soil. This can also be attributed to the higher P content of poultry droppings and NPK. Masarirambi et al. [41] also reported high levels of available phosphorus in poultry droppings, and high P uptake in soils treated with PD with a corresponding increase in crop yield. Similarly, the higher N recovery efficiency in Urine + PD compared to NPK + PD, Urine + DFS, or Urine alone can be attributed to the fairly high $\mathrm{N}$ uptake and dry matter yields especially in the dry season. The $\mathrm{N}$ use efficiencies for most of the organic inputs were within the range reported by Båth [42]. He, however, reported that the $\mathrm{N}$ efficiency when using human urine alone could be high, ranging from 47 per cent to 66 per cent.

There was a significant interactive effect of treatment and season on soil $\mathrm{NO}_{3}-\mathrm{N}$ content, with fairly high concentration in soils treated with Urine + PD in the rainy season and NPK + PD in the dry season. The implication of the high soil $\mathrm{NO}_{3}-\mathrm{N}$ content is that the possible loss is through volatilization and leaching into the environment. This might consequently contribute to greenhouse gas (GHG) emissions and the pollution of water bodies. The fairly high increase in soil $\mathrm{pH}, \mathrm{N}, \mathrm{P}$, and $\mathrm{K}$ under Urine + DFS, Urine + PD, and NPK + PD treatments gives an indication that with long-term cultivation the treatments have the potential to build soil fertility. However, the high soil $\mathrm{NO}_{3}-\mathrm{N}_{\text {content, and the }}$ doubling of soil EC to a range close to $1.5 \mathrm{dSm}^{-1}$ (salinity threshold values for the cultivation of most sensitive crops such as carrots, lettuce, etc.) is of great concern. The non-significant differences of the treatments' effects on major soil characteristics can be attributed to the short period of cultivation and the past land use practices. There is therefore the need for the continuous monitoring of the use of urine and PD and the other treatments for a longer period.

The results of the financial analysis indicate that farmers could save substantial amounts of money (\$1452-1664) when they switch from using inorganic fertilizer and poultry droppings to urine and poultry droppings or dewatered faecal sludge for cabbage production. In addition, crops grown with urine provide a relatively longer shelf life than those from inorganic fertilizer treatment (Bonzi, et al. [43]). 


\section{Conclusions}

The results suggest that urine combined with poultry droppings (PD) can be a potential source of inputs to use in vegetable production and to increase soil fertility. The implication is that the over-reliance on fertilizer will be reduced. The effect of fertilizer in reducing soil $\mathrm{pH}$, which farmers claimed is responsible for non-responsiveness of their soil, will also be minimized if not eliminated. The use of urine in crop production may indirectly contribute to changes in societal perception about urine disposal to the environment, which could consequently prevent pollution of water bodies. However, the high $\mathrm{NO}_{3}-\mathrm{N}$ in the soil under Urine +PD and NPK + PD, and the doubling of soil EC in the treatments to a range closed to $1.5 \mathrm{dSm}^{-1}$ (i.e., salinity threshold values for most sensitive crops) is of great concern. There is therefore the need to first address the following: low N recovery; high EC; as well as the antibiotics concentrations in urine and bio accumulation in food crops to ascertain the safety of urine use before it is recommended for food crop production in Ghana. Further research in different areas and soils will also be necessary.

Acknowledgments: This manuscript is the output from the SWITCH project funded by the EU. The content is based on the end of project report (www.switchurbanwater.eu) submitted to the donor. The end of project report was published as a compilation of project results from which several articles have been developed for peer reviewed journal publications. The authors also thank the farmers at the Dzorwulu farm site whose plots were used for the trials and the Water, Land and Ecosystem (WLE) program for its support during this write-up.

Author Contributions: Olufunke Cofie conceived the idea, and contributed to the writing of the manuscript; Noah Adamtey designed, performed the experiments, analysed the data, and contributed to the writing of the manuscript; Philip Amoah led in the writing of the manuscript.

Conflicts of Interest: The authors declare no conflict of interest.

\section{Appendix A}

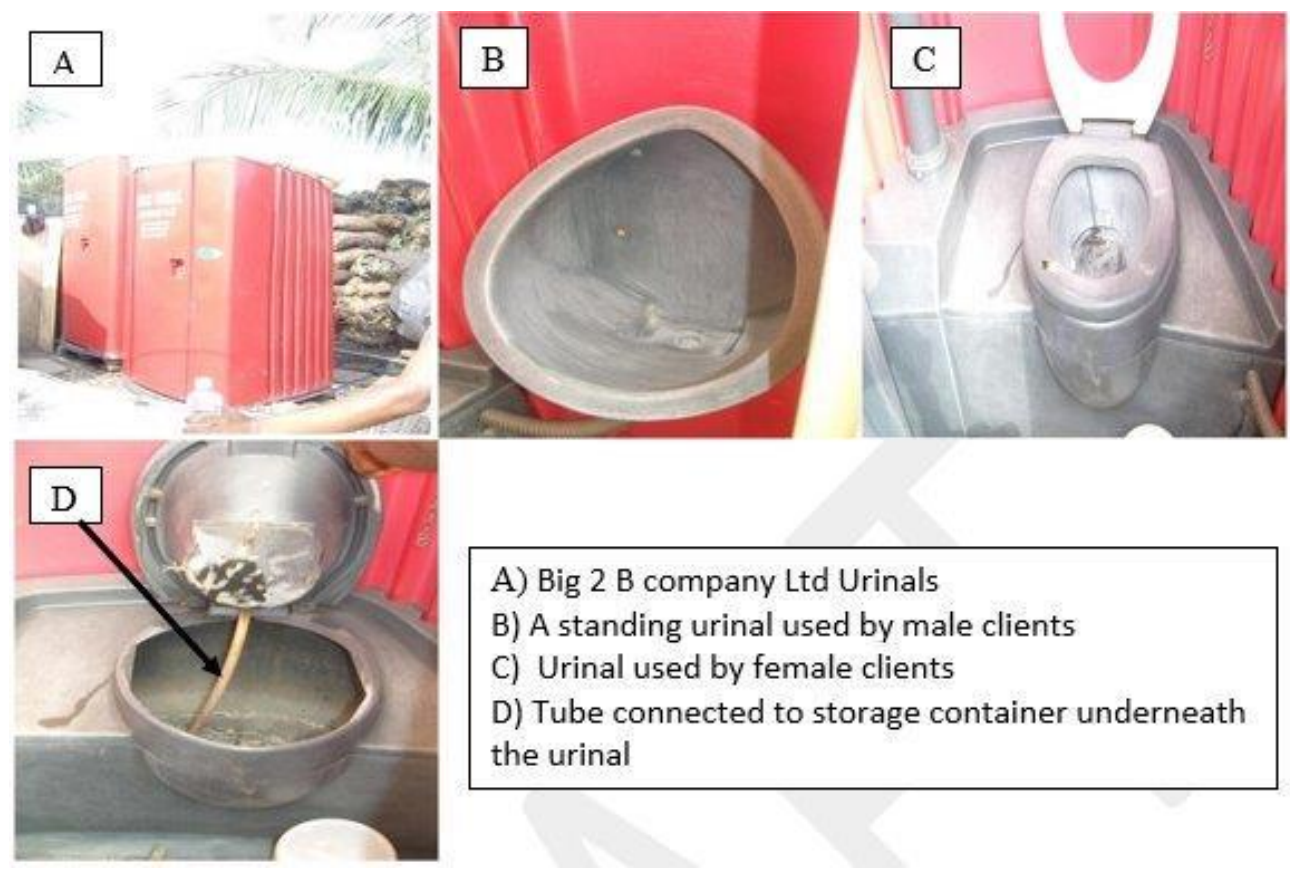

Figure A1. Urinals used for the collection of urine used in the study (photo by Mark Ofei).

\section{References}

1. United Nations (UN). World Urbanization Prospects: The 2001 Revision Data Tables and Highlights; Department of Economic and Social Affairs, Population Division: New York, NY, USA, 2002. 
2. Tettey-Lowor, F. Closing the Loop between Sanitation and Agriculture in Accra, Ghana: (Improving Yields in Urban Agriculture by Using Urine as a Fertilizer and Drivers \& Barriers for Scaling-Up). Master's Thesis, University of Wageningen, Wageningen, The Netherlands, 2007.

3. Cencosud, S.A. Urban Market Gardens in Accra; Centre for Community Studies, Action and Development and the Mega Cities Project: Accra, Ghana, 1994.

4. Drechsel, P.; Graefe, S.; Sonou, M.; Cofie, O.O. Informal Irrigation in Urban West Africa: An Overview; IWMI Research Report 102; International Water Management Institute: Colombo, Sri Lanka, 2006; ISBN: 978-92-9090-642-1.

5. Drechsel, P.; Keraita, B. Irrigate d Urban Vegetable Production in Ghana: Characteristics, Benefits and Risks Mitigation, 2nd ed.; International Water Management Institute (IWMI): Colombo, Sri Lanka, 2014; p. 247, ISBN 978-92-9090-798-5. [CrossRef]

6. Cofie, O.; Danso, G.; Larbi, T.; Kufogbe, S.K.; Obiri-Opareh, N.; Abraham, E.; Schuetz, T.; Henseler, M. Urban Agriculture in Accra, Ghana Assessing Livelihood Potentials and Policy Mechanisms; A Working Paper for the RUAF Project; International Water Management Institute (IWMI): Colombo, Sri Lanka, 2006.

7. Allen, A.; Frediani, A.A.; Wood-Hill, M. Land and Planning for Urban Agriculture in Accra: Sustained Urban Agriculture or Sustainable Urbanization? International Water Management Institute (IWMI): Colombo, Sri Lanka, 2014.

8. Centre Regional pour 1'Eau Potable (CREPA). ECOSAN Info No. 6, Septembre 2006 Bulletin d'Information du Programme Assainissement Ecologique du CREPA. Available online: http://www.reseaucrepa.org/ page/786 (accessed on 17 December 2016).

9. Sundberg, K. Vad Innehåller Avlopp Från Hushåll; Swedish Environment Protection Agency: Stockholm, Sweden, 1995.

10. Drangert, J.-O. Perceptions, urine blindness and urban agriculture. In Ecological Alternatives in Sanitation; Drangert, J.-O., Bew, J., Winblad, U., Eds.; SIDA: Balingsholm, Sweden, 1997; pp. 29-38.

11. Ganrot, Z. Urine Processing for Efficient Nutrient Recovery and Reuse in Agriculture. Ph.D. Thesis, Department of Environmental Science and Conservation, Faculty of Science, Göteborg University, Göteborg, Sweden, 2005.

12. Jönsson, $\mathrm{H}$. The role of ecosan in achieving sustainable nutrient cycles. In Ecosan-Closing the Loop; GTZ—Deutsche Gesellschaft fur Technische Zusammenarbeit: Lübeck, Germany, 2004; pp. 35-40.

13. The Impact of Source Separation of Urine on Biological Nutrient Removal Activated Sludge Plants. Available online: www.ewisa.co.za/literature/files/263213Mbaya.pdf (accessed on 15 February 2017).

14. Ghana statistical service (GSS). 2010 Housing and Population Cencus; Ghana Statistical Service: Accra, Ghana, 2010.

15. Test Methods for the Examination of Composting and Compost (TMECC). The United States Department of Agriculture and the United States Composting Council. Available online: http://tmecc.org/tmecc//2002 (accessed on 22 April 2017).

16. Black, C.A.; Evans, D.D.; White, J.L.; Ensminger, L.E.; Clark, F.E. Agronomy, No. 9, Part 2: Methods of Soils Analysis; American Society of Agronomy: Madison, WI, USA, 1965.

17. Okalebo, J.R.; Guthua, K.W.; Woomer, P.J. Laboratory Methods of Soil and Plant Analysis-A Working Manual; TSBF-CIAT and SACRED Africa Nairobi: Nairobi, Kenya, 2002.

18. Adamtey, N. Development of Compost-Fertilizer (Comlizer) for Improved Nutrient and Water Use by Urban Farmers; Project Report Submitted to IDRC-AGROPOLIS; IDRC-AGROPOLIS: Ottawa, Canada, 2006; p. 50.

19. Morgan, P. Experiments Using Urine and Humus Derived from Ecological Toilets as a Source of Nutrients for Growing Crops. In Proceedings of the 3rd World Water Forum, Kyoto, Japan, 16-23 March 2003; Available online: http:/ / aquamor.tripod.com/KYOTO.htm (accessed on 16 May 2017).

20. Kay, D.R.; Edwards, M.W.; Duffy, A.P. Farm Management, 6th ed.; McGraw-Hill Companies Inc.: New York, NY, USA, 2008.

21. Offei, M.K.; Egyir, S.; Kwadzo, G.T.-M.; Cofie, O. Financial feasibility of producing a urine-based fertiliser for vegetable farming in Accra, Ghana. J. Adv. Agric. Sci. Technol. 2014, 2. Available online: https://www. watchpub/jaast/index.htm (accessed on 20 April 2017).

22. Schuent, R.; Parkinson, J.; Knapp, A. Study for Financial and Economic Analysis of Ecological Sanitation in Sub-Saharan Africa; Water and Sanitation Program: Nairobi, Kenya, 2009.

23. Bates, D.; Martin, M.; Ben, B.; Steve, W. Fitting Linear Mixed-Effects Models Using lme4. J. Stat. Softw. 2015, 67, 1-48. [CrossRef] 
24. R Core Team. R: A Language and Environment for Statistical Computing; R Foundation for Statistical Computing: Vienna, Austria, 2016. Available online: https:/ /www.R-project.org/ (accessed on 20 April 2017).

25. Lenth, R.V. Least-Squares Means: The R Package lsmeans. J. Stat. Softw. 2016, 69, 1-33. [CrossRef]

26. Kuznetsova, A.; Per Bruun, B.; Rune, H.; Bojesen, C. LmerTest: Tests in Linear Mixed Effects Models. R Package Version 2.0-30. Available online: https:/ /CRAN.R-project.org/package=lmerTest (accessed on 20 April 2017).

27. Guadarrama, R.O.; Pichardo, N.A.; Morales-Oliver, E. Urine and compost efficiency applied to lettuce under greenhouse conditions in Temixco, Morales, Mexico. In Proceedings of the First International Conference on Ecological Sanitation, Abstract Volume, Nanning, China, 5-8 November 2001.

28. Kirchmann, H.; Pettersson, S. Human urine-Chemical composition and fertilizer efficiency. Fertil. Res. 1995, 40, 149-154. [CrossRef]

29. Johansson, M.; Jönsson, H.; Höglund, C.; Richert Stintzing, A.; Rodhe, L. Urine Separation-Closing the Nutrient Cycle; Stockholm Water Company: Stockholm, Sweden, 2001; Available online: http://www. stockholmvatten.se/pdf_arkiv/english/Urinsep_eng (accessed on 17 December 2016).

30. Rodhe, L.; Richert Stintzing, A.; Steineck, S. Ammonia emissions after application of human urine to a clay soil for barley growth. Nutr. Cycl. Agroecosyst. 2004, 68, 191-198. [CrossRef]

31. Guyton, A. Textbook of Medical Physiology; W.B. Saunders Company: Philadelphia, PA, USA, 1986.

32. Schouw, N.L.; Danteravanich, S.; Mosbaeck, H.; Tjell, J.C. Composition of human excreta, a case study from Southern Thailand. Sci. Total Environ. 2002, 286, 155-166. [CrossRef]

33. Pradhan, S.K.; Anne-Marja, N.; Sjöblom, A.; Holopainen, J.K.; Heinonen-Tanski, H. Use of human urine fertilizer in cultivation of cabbage (Brassica oleracea)-Impacts on chemical, microbial, and flavor quality. J. Agric. Food Chem. 2007, 55, 8657-8663. [CrossRef] [PubMed]

34. Schoenning, C.; Stenstroem, T.A. Guidelines on the Safe Use of Urine and Faeces in Ecological Sanitation Systems; EcoSanRes Publication Series; Stockholm Environment Institute (SEI): Stockholm, Sweden, 2004.

35. Geigy, C. Wissenschaftliche Tabellen Geigy, Teilband Körperflüssigkeiten. In Scientific tables Geigy, Volume Body Fluids, 8th ed.; Ciba-Geigy: Basel, Switzerland, 1977.

36. Udert, K.M.; Larsen, T.A.; Gujer, W. Estimating the precipitation potential in urine-collecting systems. Water Res. 2003, 37, 2667-2677. [CrossRef]

37. Udert, K.M.; Larsen, T.A.; Biebow, M.; Gujer, W. Precipitation dynamics in a urine-collecting system. Water Res. 2003, 37, 2571-2582. [CrossRef]

38. Esrey, S.A.; Gough, J.; Rapaport, D.; Sawyer, R.; Simpson-Hébert, M.; Vargas, J.; Winblad, U. Ecological Sanitation; Swedish International Development Cooperation Agency: Stockholm, Sweden, 1998.

39. Mochiah, M.B.; Osei, M.K.; Osei, K.; Pfeiffer, D.; Muniappan, R. Impact of farmer field schools on cabbage production in two Districts of Ashanti and Brong Ahafo Regions of Ghana. Int. J. Agric. Innov. Res. 2015, 2, 525-529.

40. Simons, J.; Clemens, J. The use of separated human urine as mineral fertilizer. In Ecosan-Closing the Loop; GTZ—Deutsche Gesellschaft fur Technische Zusammenarbeit: Bonn, Germany, 2004; pp. 595-600.

41. Masarirambi, M.T.; Dlamini, P.; Wahome, P.K.; Oseni, T.O. Effects of Chicken Manure on Growth, Yield and Quality of Lettuce (Lactuca sativa L.). Am. Eurasian J. Agric. Environ. Sci. 2012, 12, 399-406.

42. Båth, B. Field Trials Using Human Urine as Fertilizer to Leeks; Department of Ecology and Plant Production Science, Swedish University of Agricultural Sciences: Uppsala, Sweden, 2003. (In Swedish)

43. Bonzi, M. Experiences and Opportunities for Human Excreta Fertiliser in Improving Small Scale Agriculture, Stockholm World Water Week Presentation. 2008. Available online: http:/ /www.ecosanres.org/pdf_files/ www2008/Dr_Bonzi_14.pdf (accessed on 23 April 2017).

(C) 2017 by the authors. Licensee MDPI, Basel, Switzerland. This article is an open access article distributed under the terms and conditions of the Creative Commons Attribution (CC BY) license (http:/ / creativecommons.org/licenses/by/4.0/). 